\title{
DUPLICATION OF THE SOX3 GENE IN AN SRY-NEGATIVE 46,XX MALE WITH ASSOCIATED CONGENITAL ANOMALIES OF KIDNEYS AND THE URINARY TRACT: CASE REPORT AND REVIEW OF THE LITERATURE
}

Tasic $\mathrm{V}^{1}$, Mitrotti $\mathrm{A}^{2}$, Riepe $\mathrm{FG}^{3}$, Kulle $\mathrm{AE}^{3}$, Laban $\mathrm{N}^{1}$, Polenakovic $\mathrm{M}^{4}$, Plaseska-Karanfilska D ${ }^{4}$, Sanna-Cherchi $\mathrm{S}^{2}$, Kostovski $\mathrm{M}^{1}$, Gucev $\mathrm{Z}^{1, *}$

*Corresponding Author: Professor Dr. Zoran Gucev, University Children's Hospital, Medical Faculty Skopje, ul. Majka Tereza 17, 1000 Skopje, Republic of Macedonia. Mobile: +389-70-279-742.

E-mail: gucevz@,gmail.com

\begin{abstract}
Disorders of sex development (DSD) are a group of rare conditions characterized by discrepancy between chromosomal sex, gonads and external genitalia. Congenital abnormalities of the kidney and urinary tract are often associated with DSD, mostly in multiple malformation syndromes. We describe the case of an 11-year-old Caucasian boy, with right kidney hypoplasia and hypospadias. Genome-wide copy number variation (CNV) analysis revealed a unique duplication of about $550 \mathrm{~kb}$ on chromosome Xq27, and a 46,XX karyotype, consistent with a sex reversal phenotype. This region includes multiple genes, and, among these, $S O X 3$ emerged as the main phenotypic driver. This is the fifth case reporting a genomic imbalance involving the $S O X 3$ gene in a 46,XX SRY-negative male, and the first with associated renal malformations. Our data provide plausible links between $\mathrm{SOX} 3$ gene dosage and kidney malformations. It is noteworthy that the current and reported $S O X 3$ gene duplications are below the detection threshold of standard karyotypes and were found only by analyzing CNVs using DNA microarrays. Therefore, all 46,XX SRY-negative males should be screened for $\mathrm{SOX}_{3}$ gene duplications with DNA microarrays.

Keywords: Congenital anomalies of kidneys and the urinary tract (CAKUT); Copy number variations (CNVs); Disorders of sex development (DSD).

\footnotetext{
${ }^{1}$ Medical Faculty Skopje, Skopje, Republic of Macedonia

${ }^{2}$ Division of Nephrology, Columbia University, New York, NY, USA

${ }^{3}$ Division of Pediatric Endocrinology and Diabetes, Department of Pediatrics, University Hospital Schleswig-Holstein, ChristianAlbrechts University Kiel, Kiel, Germany

${ }^{4}$ Research Centre for Genetic Engineering and Biotechnology "Georgi D. Efremov," Macedonian Academy of Sciences and Arts, Skopje, Republic of Macedonia
}

\section{INTRODUCTION}

Sex in humans is genetically determined and is defined by the sex chromosomes (XY for males and XX for females) and by the development of gender specific anatomy, physiology and behavior. A complete or partial mismatch between genetic sex and phenotypic sex results in disorders of sexual development (DSD). Disorders of sexual development in humans have a frequency of at least one in 100 live births [1], while the frequency of "corrective" genital surgery is estimated to be between one and two per 1000 live births. There is a wide spectrum of DSD ranging from hypospadias (incidences variable from one in $\mathbf{5 0 0}$ to six in 250 births) [2] to ambiguous genitalia (incidence one in 4500 births) [3] and complete sex reversal (46,XY females and 46,XX males; one in 20,000 births) [4]. Congenital malformations of the kidney and DSD are often described in association, in the broad spectrum of multiple malformation syndromes, as it happens in Smith-Lemli-Opitz Syndrome (OMIM: 270400), a complex syndrome characterized by congenital kidney and ureteric abnormalities associated with genital anomalies and inadequate sexual hormone production $[5,6]$. Mutations of Wilms tumor $1(W T 1)$ gene may lead to Denys-Drash syndrome (OMIM: 19408), Frasier syndrome (OMIM: 13668) or Wilms aniridia genitourinar renal (WAGR) syndrome (OMIM: 194072), which are characterized by kidney and genitourinary diseases in association with internal and external genitalia defects [7-10] and mostly 46,XY female phenotypes. The sex-determining region $Y$ (SRY) is considered to be the main regulator of male sex determination in mammals [1,11]. The main function of SRY in sex determination is to upregulate its direct target gene SOX9, thus initiating Sertoli cell differentiation $[12,13,14]$. The SRY-related HMG box-containing gene 3 (SOX3) is a member of a family of $20 \mathrm{SOX}$ genes, structurally similar to 
SRY [15]. This gene is located on the $X$ chromosome and it consists of a single exon [16]. The $S O X 3$ gene encodes for a transcription factor expressed in the central nervous system (CNS) of vertebrate embryos, which is essential for pituitary, craniofacial and neuronal development [15-22].

Prior human genetics studies implicated $S O X 3$ in brain development and gender determination. Laumonnier et al. [17] described a pericentric inversion of the X chromosome involving the IL1RAPL at Xp21.3 and the polyalanine repeat of $S O X 3$ at $\mathrm{Xq} 26.3$, in a 10-year-old girl affected a by mild memory deficiency, strabism, speech impairment and hypotonia; because previous studies showed that female carriers of microdeletions involving IL1RAPL do not show intellectual disability $[23,24]$, the phenotype was likely attributable to another gene in the duplicated region. Analysis of an independent family segregating $\mathrm{X}$-linked intellectual disability demonstrated an in-frame duplication of $33 \mathrm{bp}$ involving a polyalanine repeat of $S O X 3$, thus pointing to SOX3 mutations as the cause of neurodevelopmental delay.

A sub-microscopic duplication of $685.6 \mathrm{~kb}$ at Xq27.1 involving $\mathrm{SOX}_{3}$, has been reported in two siblings affected by hypopituitarism and abnormalities of corpus callosum, while a duplication involving the $S O X 3$ polyalanine repeat was identified in three male siblings from another family, segregating panhypopituarism and abnormalities of the pituitary gland: all of these patients had absent infundibulum and did not present an intellectual disability [18]. A duplication of $3.9 \mathrm{Mb}$ involving the $\mathrm{Xq} 27$ region containing $S O X 3$, has been reported in males affected by X-linked hypopituitarism [25]. In a study of 16 SRY-negative 46,XX male patients, DNA microarray analysis showed genomic rearrangements of the $S O X 3$ regulatory region in three patients, two duplications and one deletion: the CNVs involved genomic regions in close proximity of $S O X 3$ in all three patients [26].

Interestingly, a recent report described a SRY-negative, $46, \mathrm{XX}$ boy affected by ovotesticular $\mathrm{DSD}$, with hypo-spadias and cryptorchidism with a de novo duplication of a 502 $\mathrm{kb}$ fragment of the long arm of chromosome $\mathrm{X}$, involving SOX3, as well as RPS17P17, CDR and MIR 320D2. The role of the RPS17P17,CDR1 and MIR320D2 genes has not been investigated [27]. In summary, SOX3 genetic variants have been associated with $\mathrm{X}$-linked intellectual disability with isolated growth hormone deficiency as well as X-linked panhypopituitarism and 46,XX sex reversal in males. Until now, no other developmental phenotypes have been associated to $S O X 3$ gene dosage.

\section{CASE PRESENTATION}

We were consulted on a 11-year-old white Caucasian male for the findings of hypoplasia of the right kidney and coronal moderate hypospadias, after surgical correction of

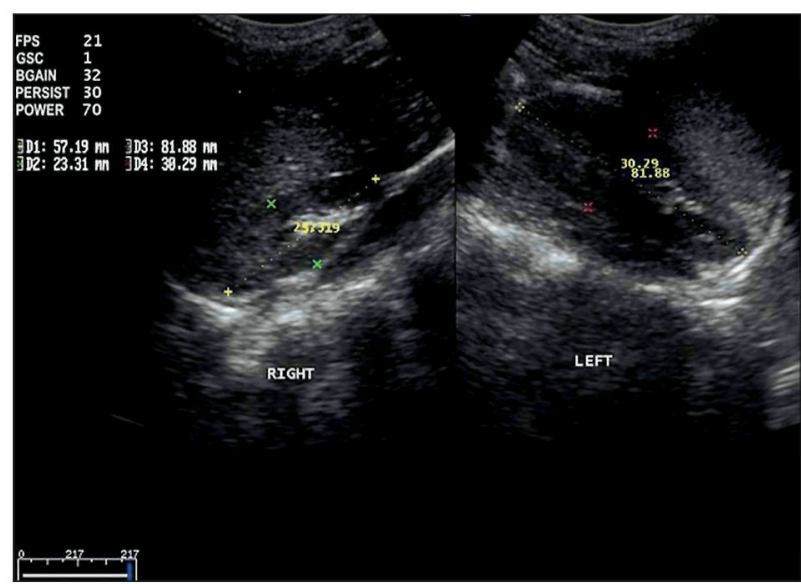

Figure 1. Ultrasound images showing hypoplasia of the right kidney measuring $57 \times 23 \mathrm{~mm}$ compared to a normal size left kidney $80 \times 32 \mathrm{~mm}$.

the urethra anomaly. He was the first child of a non consanguineous couple. His parents and younger sister were healthy. His intelligence was normal (IQ 92) and he had no other anomalies. The behavior, growth and development were all normal. His testes volume was $>4 \mathrm{~mL}$ and the penis length was $5 \mathrm{~cm}$. Abdominal ultrasound and magnetic resonance imaging (MRI) did not show internal female genitalia, and confirmed right kidney hypoplasia (Figure 1, Table 1). The left kidney size was $80 \times 32 \mathrm{~mm}$, while the right kidney size was $57 \times 23 \mathrm{~mm}$.

The patient was investigated as part of a study approved by the institutional review board at our International Centre for genetic Engineering and Biotechnology in Skopje (Republic of Macedonia) and at the Department of Nephrology, Columbia University, New York, NY, USA. This patient was already reported as part of our prior study on copy number variations (CNVs) in kidney malformations [28].

An additional 23 patients were selected to perform targeted Sanger resequencing of $S O X 3$. We selected 23 males affected by urinary tract developmental defects (10 renal hypodysplasia; three vescicoureteral reflux; two posterior urethral valve; four obstructive uropathy; one bladder anomaly, one ectopic, one accessory kidney and one horseshoe kidney) and associated DSD (11 hypospadias, nine cryptorchidism, one epispadia and one congenital hidrocele).

Endocrine Analysis. Plasma concentrations of steroid hormones, comprising mineralocorticoids, glucocorticoids and androgens, were determined using UPLC Quattro Premier/Xe system (Waters, Milford, MA, USA) as previously described [29-31].

In brief, aliquots of plasma samples, calibrator and controls with a volume of $0.1 \mathrm{~mL}$ were combined with an internal standard mixture to monitor recovery. All samples were extracted using Oasis MAX SPE system Plates (Waters). 
Table 1. Comparison of our patient characteristics with cases reported in the literature.

\begin{tabular}{|c|c|c|c|c|c|}
\hline References & [26] & [26] & {$[26]$} & [27] & This Study \\
\hline Parameters & Patient 1 & Patient 2 & Patient 3 & Patient 4 & Patient 5 \\
\hline Age (years) & M-30 & M-19; M-26 (histology) & M-19 months & M-30 months & M-11 \\
\hline Height & $165 \mathrm{~cm}$ & $167.5 \mathrm{~cm}$ & $75 \mathrm{~cm}$ & $87.8 \mathrm{~cm}(11.8 \mathrm{~kg})$ & $148 \mathrm{~cm}(42 \mathrm{~kg})$ \\
\hline Penis size & & $10.2 \mathrm{~cm}$ long; $2.6 \mathrm{~cm}$ wide & $3.4 \mathrm{~cm}$ long & $32 \mathrm{~mm}$ long; $13 \mathrm{~mm}$ wide & $5 \mathrm{~cm}$ \\
\hline $\begin{array}{l}\text { Testicular } \\
\text { size }\end{array}$ & $\sim 5 \mathrm{~mL}$ & $-6 \mathrm{~mL}$ & $\begin{array}{l}\text { right testicle appear } \\
\text { smaller than left testicle }\end{array}$ & & $4 \mathrm{~mL}$ \\
\hline $\begin{array}{l}\text { Genitals and } \\
\text { testes }\end{array}$ & & $\begin{array}{l}\text { scrotal hypoplasia; } \\
\text { retractile testes; histology: } \\
\text { atrophic changes with loss } \\
\text { of normal hypoplastic } \\
\text { scrotum; spermatogenesis; } \\
\text { thickening and hyaliniza- } \\
\text { tion of the tubular basal } \\
\text { lamina and diminished } \\
\text { number of interstitial } \\
\text { cells; normal spermatic } \\
\text { cords }\end{array}$ & & $\begin{array}{l}\text { cryptochidism; } \\
\text { hypospadias }\end{array}$ & $\begin{array}{l}\text { moderate coronal hypo- } \\
\text { spadias }\end{array}$ \\
\hline $\begin{array}{l}\text { Secondary } \\
\text { sexual char- } \\
\text { acteristics }\end{array}$ & normal & \begin{tabular}{|l|} 
Tanner stage 5 pubic hair \\
and penile development \\
with small testes; \\
onset age 13 years \\
\end{tabular} & NA & NA & \\
\hline \begin{tabular}{|l} 
Develop- \\
mental \\
issues
\end{tabular} & & $\begin{array}{l}\text { gender dysphoria from } \\
6 \text { years; referred to } \\
\text { behavioral therapist }\end{array}$ & $\begin{array}{l}\text { microcephaly; } \\
\text { developmental delay; } \\
\text { growth retardation }\end{array}$ & none & crossdressing \\
\hline CAKUT & - & - & - & - & $\begin{array}{l}\text { hypospadias; kidney } \\
\text { hypodysplasia }\end{array}$ \\
\hline $\begin{array}{l}\text { Genetic } \\
\text { alterations }\end{array}$ & $\begin{array}{l}\text { two microduplications } \\
\text { of } \sim 123 \text { and } 85 \mathrm{~kb} \text {, } \\
\text { the former of which } \\
\text { spanned the entire } \\
\text { SOX3 gene }\end{array}$ & $\begin{array}{l}\text { microdeletion; a single } \\
343 \mathrm{~kb} \text { immediately } \\
\text { upstream of SOX3, } \\
\text { suggesting that altered } \\
\text { regulation of } S O X 3 \\
\text { is the cause of } X X \\
\text { male sex reversal }\end{array}$ & $\begin{array}{l}\text { a large }-6 \mathrm{Mb} \text { duplication } \\
\text { that encompasses SOX3 } \\
\text { and at least } 18 \text { additional } \\
\text { distally located genes }\end{array}$ & $\begin{array}{l}\text { de novo duplication } \\
(0.5 \mathrm{Mb}) \text { at Xq27.1 } \\
\text { comprising SOX3,CDR1 } \\
\text { and MIR320D2 }\end{array}$ & $\begin{array}{l}\text { a unique } 550 \mathrm{~kb} \\
\text { duplication involving } \\
\text { SOX3, the non coding } \\
\text { RNALINCO0632, } \\
\text { AK054921, CDRI and } \\
\text { the miRNA MIR320D2 }\end{array}$ \\
\hline
\end{tabular}

NA: not available; CAKUT: congenital anomalies of the kidneys and urinary tract.

Genetic Analyses. After receiving informed consent, collected according to the Ethics Board of the Macedonian Academy of Sciences and Arts (Skopje, Republic of Macedonia), genomic DNA was obtained from peripheral blood samples using standard methods. Genome wide genotyping was conducted on patient MCD_13 using Illumina 610-Quad chip (Illumina Inc., San Diego, CA, USA) [32].

Copy number variation analysis was performed as previously described and data were compared to 21,575 multiethnic controls [28,33-35]. Briefly, genotype calls and quality-control analyses were conducted using GenomeStudio v.2010.3 (Illumina Inc.) and PLINK software [36]. Standardized genotyping methods implemented by the PennCNV program [37] were used for genome-wide CNV calls. The human reference genome hg18 (NCBI build 36.1, March 2006) was the reference assembly used to map the CNVs. The annotation of the CNVs was then performed using the UCSC RefGene and RefExon (CNVision program) [38].

Specific primers were designed to direct polymerase chain reaction (PCR) at the exon and exon-intron boundaries of $S O X 3$, and bidirectional Sanger sequencing was performed by BigDye® terminator (Nimagen BV, Nijmegen, The Netherlands) reaction followed by a run on an automatic capillary DNA sequencer. Sequence and alignment was conducted using Sequencer 5.4 software (Gene Codes Corp., Ann Arbor, MI, USA).

An adreno corticotropic hormone (ACTH) test showed normal basal and stimulated $17 \mathrm{OH}$-progesterone excluding a form of 46,XX DSD due to 21-hydroxylase deficiency. The 11-deoxycorticosterone (DOC) and 11-deoxycortisol were normal at both baseline and after ACTH stimulation, excluding 11-hydroxylase deficiency. Cortisol levels were in the mid-normal range at baseline and responded to stimulation, excluding primary adrenal insufficiency. 


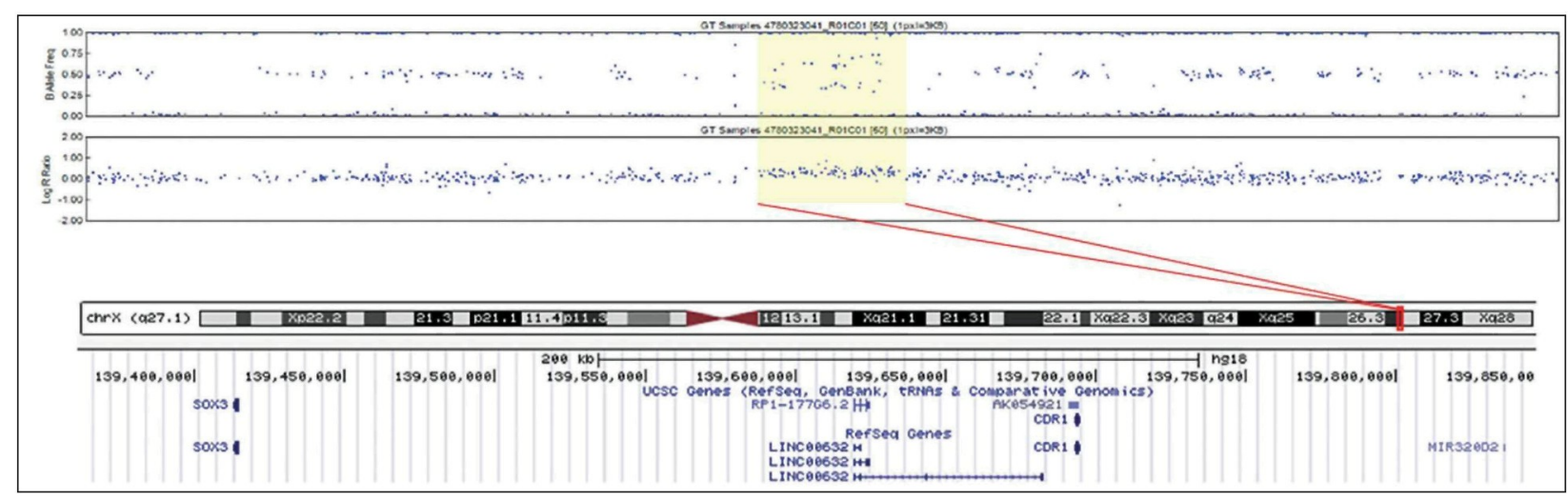

Figure 2. The $550 \mathrm{~kb}$ duplication at Xq27 (ChrX: 139,360,520-139,908,320), involving SOX3, the non coding RNA LINC00632, AK054921, CDRI and the miRNA MIR320D2.

The hCG (human chorionic gonadotrpin) test found testosterone in the low-normal range for male sex and age at baseline. After stimulation, it raised up to $146.0 \mathrm{ng} / \mathrm{mL}$ indicating the presence of functional Leydig cells targeted by hCG. The stimulated ratio A:T was below 1 , not supporting 17- $\beta$-hydroxysteroid dehydrogenase type 3 deficiency. The stimulated ratio T:DHT was 5.6, not supporting $5 \alpha$-reductase insufficiency. Microarray-based copy number analysis was previously performed in this patient as part of a larger study on congenital kidney defects [28].

In our 11-year-old male patient affected by renal dystrophy (RHD) and DSD (MCD_13), the microarray analysis showed an unique duplication of about $550 \mathrm{~kb}$ of the chromosome region $\mathrm{Xq} 27$, involving multiple genes and transcripts: $S O X 3, R P 1-177 G 6$ and $C D R 1$, the non coding RNA LINC00632, and the miRNA MIR320D2 [28] (Figure 2). None of the genes within the duplication locus has previously been reported to be in association with kidney and urinary tract phenotypes $[39,40]$. The chromosomal microarray analysis confirmed the 46,XX female karyotype. Parental DNA material was not available to test segregation; therefore, we could not verify if the Xq27 duplication was a de novo or inherited genomic imbalance. No causal mutations were detected in the 23 male patients selected for targeted resequencing indicating that $S O X 3$ coding variants might be a very rare cause of urinary tract malformations associated with DSDs.

\section{DISCUSSION}

There are four cases reported with $S O X 3$ duplications in 46,XX SRY-negative males in the literature [26,27,41] (Table 1). Two of the 46,XX male patients, 30 and 26 years old, respectively, reported by Sutton et al. [26], had normal intelligence and growth; the third one had developmental delay, growth retardation and microcephaly. The patient described by Grinspon et al. [27] had normal growth and intelligence, but was affected by hypospadias and cryptorchidism, with ovotestis and hypoplastic testis. Histology analysis showed atrophic changes and loss of normal spermatogenesis. Our patient's clinical phenotype was characterized by normal development and intelligence, DSD characterized by hypospadias and males genitalia with 46,XX karyotype, and, unique compared to all other reported patients in the literature, hypoplasia of the left kidney. Interestingly, our patient, as well as the patient described by by Grinspon et al. [27], both with karyotype 46,XX SRY-negative, were characterized by duplications involving the Xq27, encompassing the same genes: $S O X 3$, the non coding RNA LINC00632, AK054921, CDR1 and the miRNA MIR320D2.

The question is whether the kidney defect observed in our patient is biologically related to the duplication of $S O X 3$ or the other genes in the CNV, or if it represents a coincidental finding. Analysis of publicly available expression data (www.gudmap.org) indicates high expression of Sox 3 in the mouse developing bladder neck at embryonic day E13.5, thus suggesting a possible link to lower urinary tract malformations. The $S O X 3$ gene is known to be regulated by $P B X 1$ through direct interaction with its transcription binding site [42]. Interestingly, another patient with renal hypodysplasia from our cohort, was found to carry a de novo $0.51 \mathrm{~kb}$ deletion affecting $P B X 1$ [28]. Inactivation of $\mathrm{Pbx} 1$ in the mouse results in urinary malformations including renal agenesis and hypodysplasia [43]. Finally, a recent report implicates haploinsufficiency of PBX1 in the pathogenesis of syndromic forms of congenital anomalies of the kidney and urinary tract [44].

These data provide plausible links between $S O X 3$ gene dosage and kidney malformations. Formal proof of a causal link will require additional genetic and functional data. It is noteworthy that the current and reported $S O X 3$ duplications are below the detection threshold of standard karyotype and were found only by analyzing CNVs using 
DNA microarrays. Therefore, it is important to convey that all 46,XX SRY-negative males should be screened for $S O X 3$ duplications with DNA microarrays.

We report a case of an 11-year-old male with a duplication of chromosome Xq27, involving $S O X 3$, and leading to a male sex reversal and, possibly, kidney hypoplasia. This is the second case of 46,XX SRY-negative affected by DSD and characterized by CNV involving the SOX 3 locus, described so far. We speculate that the genomic duplication involving $S O X 3$ could be responsible not only for pituitary hormone deficiencies in humans and male sex reversal, but also for CAKUT. All 46,XX SRY-negative patients, should be screened for duplications affecting SOX3.

Declaration of Interest. The authors report no conflicts of interest. The authors alone are responsible for the content and writing of this article.

Funding. This study was supported by a grant from the International Centre for Genetic Engineering and Biotechnology, ICGEB Ref. No. CRP/MAC13-01.

\section{REFERENCES}

1. Blackless M, Charuvastra A, DerryckA, Fausto-Sterling A, Lauzanne K, Lee E. How sexually dimorphic are we? Review and synthesis. Am J Hum Biol. 2000; 12(2): 151-66.

2. Springer A, van den Heijkant M, Baumann S. Worldwide prevalence of hypospadias. J Pediatr Urol. 2016; 12(3): 152e1-e7.

3. Hughes IA, Nihoul-Fekete C, Thomas B, CohenKettenis PT. Consequences of the ESPE/LWPES guidelines for diagnosis and treatment of disorders of sex development. Best Pract Res Clin Endocrinol Metab. 2007; 21(3): 351-365.

4. de la Chapelle $\mathrm{A}$. The etiology of maleness in $\mathrm{XX}$ men. Hum Genet. 1981; 58(1): 105-116.

5. Johnson JA, Aughton DJ, Comstock $\mathrm{CH}$, von Oeyen PT, Higgins JV, Schulz R. Prenatal diagnosis of Smith-Lemli-Opitz syndrome, type II. Am J Med Genet. 1994; 49(2): 240-243.

6. Rutledge JC, Friedman JM, Harrod, MJ, Currarino G, Wright CG, Pinckney L, et al. A "new" lethal multiple congenital anomaly syndrome: Joint contractures, cerebellar hypoplasia, renal hypoplasia, urogenital anomalies, tongue cysts, shortness of limbs, eye abnormalities, defects of the heart, gallbladder agenesis, and ear malformations. Am J Med Genet. 1984; 19(2): 255-64.

7. Patek CE, Little MH, Fleming S, Miles C, Charlieu JP, Clarke AR, et al. A zinc finger truncation of murine WT1 results in the characteristic urogenital abnormalities of Denys-Drash syndrome. Proc Natl Acad Sci USA. 1999; 96(6): 2931-2936.

8. Berta P, Morin D, Poulat F, Taviaux S, Lobaccaro JM, Sultan C, et al. Molecular analysis of the sexdetermining region from the $\mathrm{Y}$ chromosome in two patients with Frasier syndrome. Horm Res. 1992; 37(3): 103-106.

9. Narahara K, Kikkawa K, Kimira S, Kimoto H, Ogata M, Kasai $\mathrm{R}$, et al. Regional mapping of catalase and Wilms tumor--aniridia, genitourinary abnormalities, and mental retardation triad loci to the chromosome segment 11p1305----p1306. Hum Genet. 1984; 66(23): 181-185.

10. vanHeyningen V, Bickmore WA, Seawright A, Fletcher JM, Maule J, Fekete G, et al. Role for the Wilms tumor gene in genital development? ProcNatl Acad Sci USA. 1990; 87(14): 5383-5386.

11. Waters PD, Wallis MC, Marshall Graves JA. Mammalian sex--Origin and evolution of the Y chromosome and SRY. Semin Cell Dev Biol. 2007; 18(3): 389-400.

12. Sekido $\mathbf{R}$, Lovell-Badge $\mathbf{R}$. Sex determination involves synergistic action of SRY and SF1 on a specific Sox9 enhancer. Nature. 2008; 453(7197): 930-934.

13. Sekido R, Bar I, Narvaez V, Penny G, Lovell-Badge R. SOX9 is up-regulated by the transient expression of SRY specifically in Sertoli cell precursors. Dev Biol. 2004; 274(2): 271-279.

14. Palmer SJ, Burgoyne PS. In situ analysis of fetal, prepuberal and adult XX----XY chimaeric mouse testes: Sertoli cells are predominantly, but not exclusively, XY. Development. 1991; 112(1): 265-268.

15. Stevanovic M, Lovell-Badge $R$, Collignon J, Goodfellow PN. SOX3 is an X-linked gene related to SRY. Hum Mol Genet. 1993; 2(12): 2013-2018.

16. Collignon J, Sockanathan S, Hacker A, Cohen-Tannoudji M, Norris D, Rastan S, et al. A comparison of the properties of Sox-3 with Sry and two related genes, Sox-1 and Sox-2. Development. 1996; 122(2): 509-520.

17. Laumonnier $\mathrm{F}$, Ronce $\mathrm{N}$, Hamel BC, Thomas $\mathrm{P}$, Lespinasse J, Raynaud M, et al. Transcription factor SOX 3 is involved in X-linked mental retardation with growth hormone deficiency. Am J Hum Genet. 2002; 71(6): 1450-1455.

18. Woods KS, Cundall M, Turton J, Rizotti K, Mehta A, Palmer R, et al. Over- and underdosage of SOX3 is associated with infundibular hypoplasia and hypopituitarism. Am J Hum Genet. 2005; 76(5): 833-849. 
19. Rizzoti K, Brunelli S, Carmignac D, Thomas PQ, Robinson IC, Lovell-Badge R. SOX 3 is required during the formation of the hypothalamo-pituitary axis. Nat Genet. 2004; 36(3): 247-255.

20. Dee CT, Hirst CS, Shih YH, Tripathi VB, Patient RK, Scotting PJ. Sox 3 regulates both neural fate and differentiation in the zebrafish ectoderm. Dev Biol. 2008; 320(1): 289-301.

21. Bylund M, Andersson E, Novitch BG, Muhr J. Vertebrate neurogenesis is counteracted by Sox1-3 activity. Nat Neurosci. 2003; 6(11): 1162-1168.

22. Rizzoti K, Lovell-Badge R. SOX3 activity during pharyngeal segmentation is required for craniofacial morphogenesis. Development. 2007; 134(19): 3437-3448.

23. des Portes V, Carrie A, Billuart P, Kieffer V, Bienvenu $\mathrm{T}$, Vinet $\mathrm{MC}$, et al. Inherited microdeletion in Xp21.322.1 involved in non-specific mental retardation. Clin Genet. 1998; 53(2): 136-141.

24. Carrie A, Jun L, Bienvenu T, Vinet MC, McDonell $\mathrm{N}$, Couvert $\mathrm{P}$, et al. A new member of the IL-1 receptor family highly expressed in hippocampus and involved in X-linked mental retardation. Nat Genet. 1999; 23(1): 25-31.

25. Solomon NM, Ross SA, Morgan T, Belsky JL, Hol FA, Karnes PS, et al. Array comparative genomic hybridisation analysis of boys with $\mathrm{X}$ linked hypopituitarism identifies a 3.9 $\mathrm{Mb}$ duplicated critical region at Xq27 containing SOX3. J Med Genet. 2004; 41(9): 669-678.

26. Sutton E, Hughes J, White S, Sekido R, Tan J, Arboleda $\mathrm{V}$, et al. Identification of SOX3 as an XX male sex reversal gene in mice and humans. J Clin Invest. 2011 ; 121(1): 328-341.

27. Grinspon RP, Nevado J, Mori Alvarez Mde L, Del Rey $\mathrm{G}$, Castera $\mathrm{R}$, Venara $\mathrm{M}$, et al. $46, \mathrm{XX}$ ovotesticular DSD associated with a SOX3 gene duplication in a SRY-negative boy. Clin Endocrinol (Oxf). 2016; 85(4): 673-675.

28. Sanna-Cherchi S, Kiryluk K, Burgess KE, Bodria M, Sampson MG, Hadley D, et al. Copy-number disorders are a common cause of congenital kidney malformations. Am J Hum Genet. 2012; 91(6): 987-997.

29. Kulle AE, Riepe FG, Melchior D, Hiort O, Holterhus PM. A novel ultrapressure liquid chromatography tandem mass spectrometry method for the simultaneous determination of androstenedione, testosterone, and dihydro-testosterone in pediatric blood samples: Ageand sex-specific reference data. J Clin Endocrinol Metab. 2010; 95(5): 2399-2409.
30. Kulle AE, Welzel M, Holterhus PM, Riepe FG. Implementation of a liquid chromatography tandem mass spectrometry assay for eight adrenal C-21 steroids and pediatric reference data. Horm Res Paediatr. 2013; 79(1): 22-31.

31. Kulle AE, Riepe FG, Hedderich J, Sippell WG, Schmitz J, Niermeyer L, et al. LC-MS/MS based determination of basal- and ACTH-stimulated plasma concentrations of 11 steroid hormones: Implications for detecting heterozygote CYP21A2 mutation carriers. Eur J Endocrinol. 2015; 173(4): 517-524.

32. Padmanabhan $\mathrm{S}$, Melander $\mathrm{O}$, Johnson $\mathrm{T}$, Di Blasio AM, Lee WK, Gentilini D, et al. Genome-wide association study of blood pressure extremes identifies variant near UMOD associated with hypertension. PLoS Genet. 2010; 6(10): e1001177.

33. Verbitsky M, Sanna-Cherchi S, Fasel DA, Levy B, Kiryluk K, Wuttke M, et al. Genomic imbalances in pediatric patients with chronic kidney disease. J Clin Invest. 2015; 125(5): 2171-2178.

34. Westland R, Verbitsky M, Vukojevic K, Perry BJ, Fasel DA, Zwijnenburg PJ, et al. Copy number variation analysis identifies novel CAKUT candidate genes in children with a solitary functioning kidney. Kidney Int. 2015; 88(6): 1402-1410.

35. Lopez-Rivera E, Liu YP, Verbitsky M, Anderson BR, Capone VP, Otto EA, et al. Genetic drivers of kidney defects in the DiGeorge syndrome. N Engl J Med. 2017; 376(8): 742-754.

36. Purcell S, Neale B, Todd-Brown K, Thomas L, Ferreira MA, Bender D, et al. PLINK: A tool set for whole-genome association and population-based linkage analyses. Am J Hum Genet. 2007; 81(3): 559-575.

37. Wang K, Li M, Hadley D, Liu R, Glessner J, Grant SF, et al. PennCNV: An integrated hidden Markov model designed for high-resolution copy number variation detection in whole-genome SNP genotyping data. Genome Res. 2007; 17(11): 1665-1674.

38. Sanders SJ, Ercan-Sencicek AG, Hus V, Luo R, Murtha MT, Moreno-De-Luca D, et al. Multiple recurrent de novo CNVs, including duplications of the 7q11.23 Williams syndrome region, are strongly associated with autism. Neuron. 2011; 70(5): 863-885.

39. Lagerstrom-Fermer M, Sundvall M, Johnsen E, Warne GL, Forrest SM, Zajac JD, et al. X-linked recessive panhypopituitarism associated with a regional duplication in Xq25-q26. Am J Hum Genet. 1997; 60(4): 910-916. 
40. Hamel BC, Smits AP, Otten BJ, van den Helm B, Ropers HH, Mariman EC. Familial X-linked mental retardation and isolated growth hormone deficiency: Clinical and molecular findings. Am J Med Genet. 1996; 64(1): 35-41.

41. Gucev Z, Tasic V, Plaseska-Karanfilska D, Konstantinova MK, Stamatova A, Dimishkovska $\mathrm{M}$, et al. LHX4 gene alterations: Patient report and review of the literature. Pediatr Endocrinol Rev. 2016; 13(4): 749-755.

42. Mojsin M, Stevanovic M. PBX1 and MEIS1 up-regulate $\mathrm{SOX} 3$ gene expression by direct interaction with a consensus binding site within the basal promoter region. Biochem J. 2009; 425(1): 107-116.
43. Schnabel CA, Godin RE, Cleary ML. Pbx1 regulates nephrogenesis and ureteric branching in the developing kidney. Dev Biol. 2003; 254(2): 262-276.

44. Le Tanno P, Breton J, Bidart M, Satre V, Harbuz R, Ray PF, et al. PBX1 haploinsufficiency leads to syndromic congenital anomalies of the kidney and urinary tract (CAKUT) in humans. J Med Genet. 2017; 54(7): 502-510. 